\title{
REPLACEMENT OF HIV p24 Ag TEST BY A MULTIPLEX RT-PCR METHOD FOR PRIMARY SCREENING OF BLOOD DONORS
}

\author{
José Eduardo LEVI(1,2), Silvano WENDEL(1,2), Deise Tihe TAKAOKA(2), Isabela Cristina SILVA(2), Juliana Polachini de CASTRO(2), Mário A. TOREZAN-FILHO(1,2), \\ Jorge GHANAME(3), Romualdo GIOACHINI(4,5), Joselito BRANDÃO(5), Evaldo Pasquini LANDI(6), Antônio César TEIXEIRA(7) \& Edison Luis DURIGON(8)
}

\begin{abstract}
SUMMARY
Nucleic Acid Testing (NAT) as a tool for primary screening of blood donors became a reality in the end of the 1990 decade. We report here the development of an "in-house" RT-PCR method that allows the simultaneous (multiplex) detection of HCV and HIV-RNA in addition to an artificial RNA employed as an external control. This method detects all HIV group M subtypes, plus group $\mathrm{N}$ and $\mathrm{O}$, with a detection threshold of $500 \mathrm{IU} / \mathrm{mL}$. After validation, the method replaced p24 Ag testing, in use for blood donation screening since 1996 at our services. From July 2001 to February 2006, 102,469 donations were tested and 41 (0.04\%) were found HIV-RNA reactive. One NAT-only reactive donation (antibody non-reactive) was observed, with subsequent seroconversion of the implied donor, giving a yield of 1:102,469. This rate is in contrast to the international experience that reports a detection of approximately 1:600,000 - 1:3,100,000 of isolated HIV-RNA donations.
\end{abstract}

KEYWORDS: Nucleic Acid Testing; Blood Donors; RT-PCR; Transfusional Risk; Human Immunodeficiency Virus; p24 Ag.

\section{INTRODUCTION}

The main driving force for NAT introduction in the blood bank, as a tool for screening, was the recognized deficiency of HCV antibody tests, in part due to the long window period observed for this agent, of approximately 90 days. After HCV NAT was established, the next target became $\mathrm{HIV}^{5}$. Even though several pharmacoeconomic studies pointed to the low cost-benefit relationship for NAT HIV ${ }^{6}$, it was introduced worldwide. This was justified by the premise that adding new targets to an existing NAT assay would aggregate value to the test, but also matching the zero tolerance claimed by the public opinion for HIV transfusional transmission. An antigenic test (p24 Ag) had already been implemented in the hope to shorten the window period, but results were fairly disappointing, in comparison to the predicted yield of this test before implantation ${ }^{17}$. In general, the observed yield of HIV NAT was very low, ranging from 0 per million in several European countries to 3.7 per million in Hong Kong, being the USA the country with the largest number of donations tested $(37,000,000)$ and a yield of $0.32 /$ $1,000,000$ obtained $^{4}$. Germany was the pioneer country in the adoption of NAT for blood screening, and up today, about $80 \%$ of the blood supply in this country is tested by "in-house" procedures. There are different molecular methods in place but all them have to comply with the regulations of the Paul-Ehrlich Institute. After testing 21,700,000 donations the yield of HIV-NAT is similar to the USA, six window- period donations were detected, giving a rate of 0.28 per million ${ }^{4}$. Scotland and Ireland also have employed an "in-house" method for their screening, beginning with HCV-RNA testing in July of 1999 and HIV-RNA afterwards, in January of 2003. After testing 771,059 donations, one single HIV NAT-only donation has been detected ${ }^{7}$. All these countries adopting "in-house" methods have used RT-PCR with gel electrophoresis detection in an early phase, subsequently migrating to real-time PCR, when this became available.

As we had introduced NAT HCV ${ }^{10,20}$ in 1998, our development was framed by the idea of within a similar methodological configuration, add HIV-RNA testing, at a minimal increase in cost and without affecting the sensitivity and overall performance of the test.

Towards that, we decided to include HIV-RNA in the existing system, as a third target in a multiplex RT-PCR reaction (HCV, external control and HIV). Several primer pairs were challenged with great variability in sensitivity and specificity. All changeable parameters in the PCR reaction were tested: magnesium chloride concentration, amount of polymerase and cycling incubation time/temperature. After two years, the method was considered ready to go, and submitted to an extensive validation phase. We present here a description of the method plus validation data and results obtained in routine application.

(1) Banco de Sangue, Hospital Sírio Libanês, São Paulo, SP, Brasil.

(2) Centro de Imunologia e Imunogenética, São Paulo, SP, Brasil.

(3) Banco de Sangue, Hospital Nove de Julho, São Paulo, SP, Brasil

(4) Banco de Sangue, Hospital Oswaldo Cruz, São Paulo, SP, Brasil.

(5) Banco de Sangue, Hospital Evaldo Foz, São Paulo, SP, Brasil.

(6) Núcleo de Hemoterapia de Bragança Paulista, Universidade São Francisco, Bragança Paulista, SP, Brasil.

(7) Hemolago,Clínica de Hematologia e Hemoterapia do Lago Sul, Brasília, DF, Brasil.

(8) Departamento de Microbiologia, Instituto de Ciências Biomédicas, Universidade de São Paulo, São Paulo, SP, Brasil.

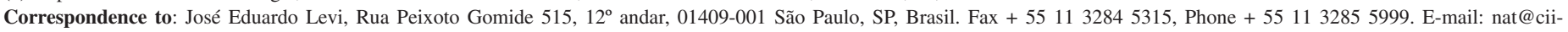
laboratorio.com.br 


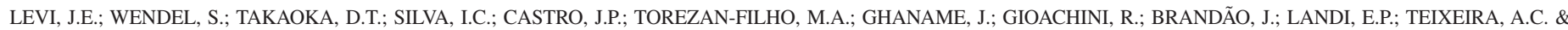
DURIGON, E.L. - Replacement of HIV p24 Ag test by a multiplex RT-PCR method for primary screening of blood donors. Rev. Inst. Med. trop. S. Paulo, 49(3): 171-176, 2007.

\section{MATERIAL AND METHODS}

a) Donors and donations: Voluntary blood donors gave written informed consent for participation in this ongoing study. For this purpose a Serum Separation Tube (SST II, Becton-Dickinson, São Paulo, Brazil) was drawn right after collection of the blood bag. Tubes were centrifuged according to manufacturer instructions and transported to the molecular biology lab on the same day. Some donations were eventually kept refrigerated and transported at $4-8{ }^{\circ} \mathrm{C}$ to the molecular biology lab on the following day. All donations were tested in parallel at the serology lab for the mandatory screening tests (anti-HCV, antiHTLV-I/II, anti-HBc and HBsAg, anti-HIV 1 and 2, Chagas, Syphilis, and abnormal hemoglobin detection). Donations were collected between July $1^{\text {st }} 2001$ and February $28^{\text {th }} 2006$ at blood banks in São Paulo city (Hospital Sírio Libanês, Hospital Nove de Julho, Hospital Oswaldo Cruz, Hospital Evaldo Foz), Bragança Paulista (Núcleo de Hemoterapia de Bragança Paulista, São Paulo State) and Brasília (Hemolago, Federal District). More than $95 \%$ of the donors lived in São Paulo city at the time of donation.

\section{b) Serology}

b1) Anti-HIV: In compliance to the Brazilian legislation ${ }^{12}$, two tests with distinct antigenic composition were adopted. In the time period described, a combination of either two assays from ABBOTT (AXSYM MEIA HIV $1 / 2 \mathrm{gO}$, or Anti_HIV $1 / 23^{\text {rd }}$ Generation PLUS, Wiesbaden Delkenheim, Germany), MUREX Ice HIV 1.0.2 (Singapore Science Park, Singapore) or ORTHO Anti-HIV 1+2 Ab Capture (Amersham, Bucks, UK) were performed, according to manufacturer's instructions.

b2) Western blot: For EIA repeatedly reactive donations, HIV Blot 2.2 (Genelabs Diagnostics, Syngapore) was performed on a new sample, collected upon return of the donor to the blood bank. Reactivity was assigned according to manufacturer's guidelines.

c) NAT method: The process of donations pooling, RNA extraction and cDNA synthesis are described in an accompanying article ${ }^{20}$.

c1) Multiplex PCR: $10 \mu \mathrm{L}$ of cDNA was added to a PCR mixture containing six primers (HCV, HIV, Control, Table 1), glycerol 5\%, cresol red $0.25 \mu \mathrm{g} / \mu \mathrm{L}$, dNTPs $0.2 \mathrm{mM}(\mathrm{A}, \mathrm{C}, \mathrm{G}, \mathbf{U}), 1.25 \mathrm{U}$ of Platinum

Table 1

Primers used in the NAT Multiplex assay

\begin{tabular}{lr}
\hline Primer & $\begin{array}{c}\text { Sequence 5' } \rightarrow \text { 3' } \\
\text { HCV 5' UTR Primers }\end{array}$ \\
\hline SM 3 (sense) & CTAGCCATGGCGTTAGTA \\
HC 18 (antisense) & GGTCACGGTCTACGAGACCT \\
\hline DM 151 (sense) & GTCTCTGAATCAGAAATCCTTCTATC \\
DM 152 (antisense) & CATGTCAAATTCACTGCTTCATCC \\
\hline & HIV LTR Primers \\
\hline LTR A1352 (sense) & GRAACCCACTGCTTAASSCTCAA \\
LTR A1353 (antisense) & TGTTCGGGCGCCACTGCTAGAGA \\
\hline
\end{tabular}

Taq (Invitrogen, São Paulo, Brazil), 0.03U of Uracyl-N-Glycosilase (Amersham, São Paulo, Brazil) in a final volume of $25 \mu \mathrm{L}$. This mixture was submitted to the following thermocycling parameters: $95{ }^{\circ} \mathrm{C}$ for five minutes, then 40 cycles of $94{ }^{\circ} \mathrm{C} / 30$ seconds; $55{ }^{\circ} \mathrm{C} / 30$ seconds; $65^{\circ} \mathrm{C} /$ one minute, and a final incubation step at $65^{\circ} \mathrm{C}$ for seven minutes. HIV LTR primers were described by CLELAND et al. ${ }^{3}$.

c2) Electrophoresis: PCR products from the External Control (EC, 308 bp), the HCV Untranslated Region (268 bp) and HIV LongTerminal Repeat (LTR, 188 bp) were run at $200 \mathrm{mV} / 100 \mathrm{~mA}$ for one hour on an ethidium bromide stained $3 \%$ agarose gel and directly observed under UV light on an UV Imager (Ultra-Violet Products, Cambridge, UK). All images were digitalized and stored, allowing the traceability of the results. A legend was engraved on the gel image and a photo printed in a thermal printer, accompanying the daily working sheet.

c3) Validation of NAT: This method was validated for routine use by:

c3.1) Sensitivity: Lyophilized WHO standards, purchased from the National Institute for Biological Standards and Controls (NIBSC, Potters Bar, Herts, UK, HIV-RNA International Standard Cat. \# 97/656 I) were reconstituted in RNAse free- $\mathrm{ddH}_{2} \mathrm{O}$ and diluted with negative plasma to the desired concentrations. Twenty replicates were run three times at five dilution points namely 1,000 IU/mL; $500 \mathrm{IU} / \mathrm{mL} ; 250 \mathrm{IU} / \mathrm{mL} ; 50$ $\mathrm{IU} / \mathrm{mL}$ and $10 \mathrm{IU} / \mathrm{mL}$ of HCV-RNA. The detection threshold of the method was $500 \mathrm{IU} / \mathrm{mL}$ HIV-RNA (95\% hit rate, Table 2).

Table 2

Sensitivity estimation of the test when challenged against a quantified international standard

\begin{tabular}{cc}
\hline $\begin{array}{c}\text { HIV-RNA International } \\
\text { Standard Concentration } \\
(\text { IU/mL) }\end{array}$ & $\begin{array}{c}\text { Reactive samples/ } \\
\text { N tested }\end{array}$ \\
\hline 5,000 & $60 / 60$ \\
500 & $60 / 60$ \\
250 & $49 / 60$ \\
100 & $27 / 60$ \\
50 & $7 / 60$ \\
\hline
\end{tabular}

c3.2) Specificity: On testing 1,000 seronegative donations there was no sample assigned as "initially reactive". In quality control blind panels, no negative sample was assigned as reactive.

c3.3) Reproducibility: Assessed by running in parallel to serological routine for two months and performance of three distinct operators. The method was shown to be robust and reproducible, independent of operator, provided that the technician was properly trained.

c3.4) Genotypic coverage: HIV-RNA Genotype Panel for NAT (NISBC code 01/466) was purchased from NISBC. Panel contains samples representing subtypes A, B, C, D, AE, F, G, AG-GH, group $\mathrm{N}$ and group $\mathrm{O}$. All samples were detected by the method both individually (Fig. 1) and in pools. 


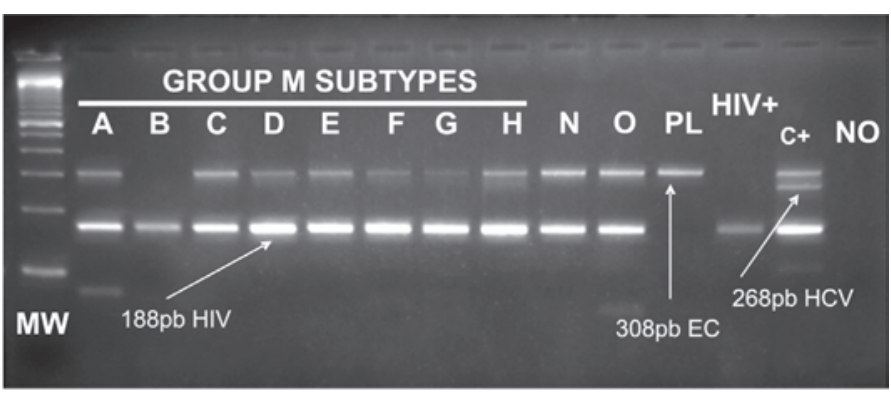

$\mathrm{HIV}+=$ positive control consisting of HIV WHO Standard at $500 \mathrm{IU} / \mathrm{mL}$. PL $=$ plasma sample non-reactive for HCV and HIV antibodies and RNAs. C+ = a pool of cDNAs from HIV and HCV Standards. MW = molecular weight marker, 100bp ladder (Invitrogen, São Paulo, Brazil). EC $=$ External Control. No $=$ no DNA control, $\mathrm{H}_{2}$ Odd was added to the PCR mix.

Fig. 1 - Validation of multiplex NAT for genotypic coverage with a panel containing HIV subtypes A-H (group $\mathrm{M}$ ), and groups $\mathrm{N}$ and $\mathrm{O}$.

c3.5) External assessment: Yearly participation on blind panels prepared for quality control on NAT labs (Viral Quality Control Program VQC, organized by CLB, Amsterdam, Netherlands). All samples containing more than $500 \mathrm{IU} / \mathrm{mL}$ of HIV-RNA were correctly assigned as reactive. No false-positives were observed.

d) Seroconversion samples: Two HIV seroconversion samples were tested. They were included as they were regular donations and readily detected by our method. One is a p24 Ag reactive sample detected at our laboratory ${ }^{19}$ and the other is a NAT-only reactive donation detected at another service ${ }^{18}$ and generously provided to us by Dr. Orlando Costa Ferreira Jr. (Blood Bank, Hospital Israelita Albert Einstein, São Paulo, Brazil). We also determined the viral load from both samples; the former contained more than 750,000 copies $/ \mathrm{mL}$ while the latter harbored 22,150 copies $/ \mathrm{mL}$.

e) Confirmatory NAT assays: Repeatedly reactive samples were submitted to an alternative NAT test, either on the same sample or from a new one collected from the donor. HIV repeatedly reactive samples were submitted to a commercial HIV viral load method (Roche HIV-Monitor v 1.5) by an ultra-sensitive procedure with a threshold of 50 copies $/ \mathrm{mL}$ according to the manufacturer instructions.

f) Controls: On each run four controls were included from the extraction; triplicates of the reconstituted international standards containing $500 \mathrm{IU} / \mathrm{mL}$ of both $\mathrm{HCV}$ and HIV-RNAs and one seronegative and NAT negative plasma. An amplification control was included at the PCR step consisting of a "pool" of cDNAs from these standards, previously shown to correctly amplify HCV and HIV. It was required two out of three replicates to amplify HCV and HIV RNA to validate the entire run. A negative result for HCV and HIV RNA on the negative control was mandatory; otherwise every reactive result was considered invalid. A positive result for the external control on the "no DNA" tube made the full run invalid. The previously obtained cDNA "pool" from standards served to guide us in case of a run failure, i.e. if the run was completely negative, but this amplification control was correct, we would have started again from extraction; if this control failed we started from the PCR step onwards. Fig. 2 is an example of such a routine run.

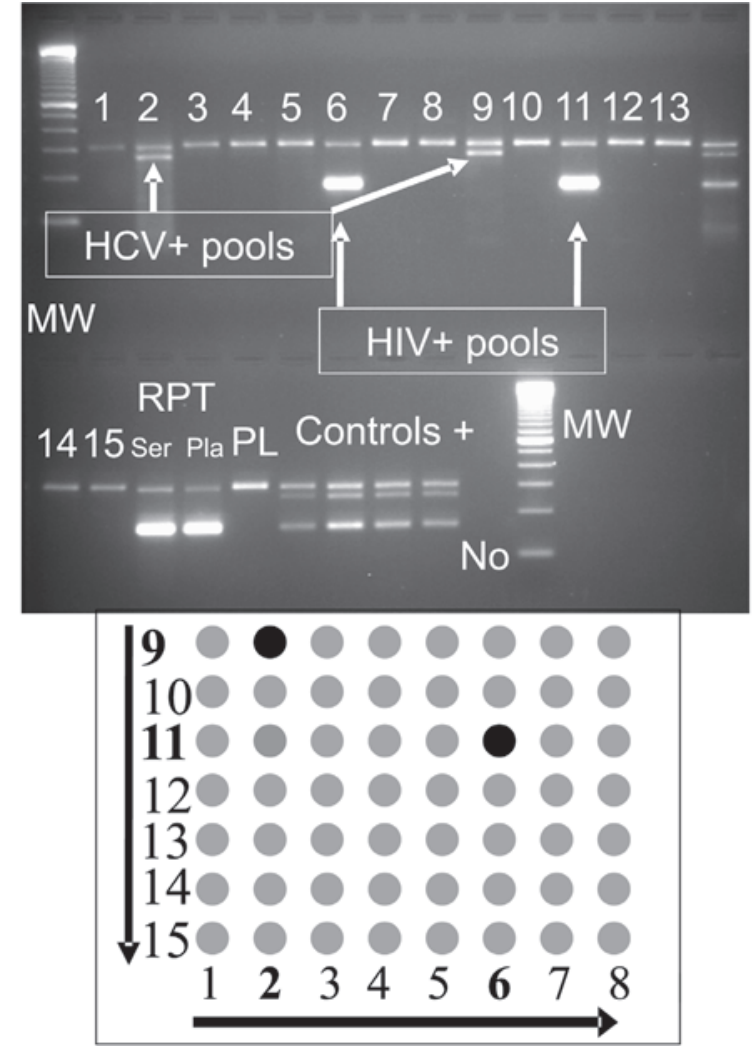

MW = molecular weight marker 100bp ladder (Invitrogen, São Paulo, Brazil). Controls $+=3$ positive controls containing each $500 \mathrm{IU} / \mathrm{mL}$ of both HCV and HIV RNA, the fourth is a cDNA of these generated previously; RPT Ser and RPT Pla = An HIV NAT reactive donation detected in the previous day and repeated individually from both serum and plasma; $\mathrm{PL}=\mathrm{HCV}$ and HIV RNA negative plasma; $\mathrm{No}=$ no DNA control, $\mathrm{H}_{2} \mathrm{Odd}$ was added to the PCR mix.

Fig. 2 - Routine analysis in a rare situation where both HCV (pools 2 and 9) and HIV (pools 6 and 11) reactive donations were detected. Pools are numbered from left to right.

\section{RESULTS}

a) Blood Donors Screening: The method described above has been in use as a routine since July 2001, replacing p24 Ag detection. Until February 2006, a total of 102,469 donations were tested for HIV RNA. 35,906 PCR reactions were performed, counting pools and controls. Forty-one samples were NAT initially reactive $(0.04 \%)$ demanding their testing individually on the next day routine. 1,147 samples were blocked for inadequacy (1.12\%; external control non-reactive) demanding their inclusion in pools in the next day routine. By serology, 366/102,469 donations $(0.36 \%)$ were rejected due to repeatedly reactive results, while NAT rejected 41/102,469 (0.04\% - see Table 3$)$. There was one NAT false positive $(1 / 102,469$ or $0.001 \%)$, which was negative for the NAT HIV confirmatory assay and one confirmed NAT-only donation $(1: 102,469)$. All blot reactive samples were concomitantly PCR reactive and the negative concordance was $100 \%$ as well (Table 4). All blot indeterminate samples were NAT non-reactive.

b) Seroconversion sample: One donation was identified as NAT reactive/EIA non-reactive. According to the working flow, this sample 


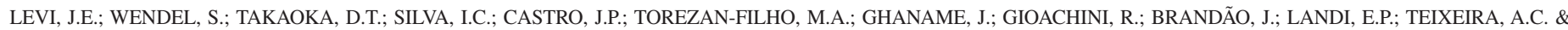
DURIGON, E.L. - Replacement of HIV p24 Ag test by a multiplex RT-PCR method for primary screening of blood donors. Rev. Inst. Med. trop. S. Paulo, 49(3): 171-176, 2007.

Table 3

HIV-NAT/EIA results $(\mathrm{n}=102,469$ donations $)$

\begin{tabular}{lcc}
\hline Test result & $\mathrm{n}$ & $\%$ \\
\hline Rejected for (EIA) anti-HIV* & 366 & 0.36 \\
Rejected for HIV-NAT & 41 & 0.04 \\
EIA non-reactive/ NAT reactive & $2^{\circledR}$ & 0.002 \\
\hline
\end{tabular}

* Donations repeatedly reactive for one or two EIA anti-HIV tests. ${ }^{\circledR}$ One sample was not reactive by the NAT confirmatory method (false-positive), the other truly NAT-isolated donation is described in detail in the text.

Table 4

HIV-RNA/Western blot results $(\mathrm{n}=366$ EIA repeatedly reactive donations +1 NAT-only)

\begin{tabular}{llcc}
\hline W. Blot & NAT & $\mathrm{n}$ & $(\%)^{*}$ \\
\hline Reactive & Reactive & 33 & 13 \\
Reactive & Non-reactive & 0 & 0 \\
Non-reactive & Reactive & 0 & 0 \\
Non-reactive & Non-reactive & 162 & 62 \\
Indeterminate & Reactive & $1^{\#}$ & 0.4 \\
Indeterminate & Non-reactive & 64 & 24.6 \\
Not done & Reactive & 6 & - \\
Not done & Non-reactive & 101 & - \\
\hline & Total & 367 & 100 \\
\hline
\end{tabular}

* Excluding the 107 samples for which Western blot was not done because a second sample was not provided. \# The single NAT-only sample that according to the standard procedure wouldn't be submitted to W. blot since it was EIA non-reactive.

was re-tested individually on the next day, displaying again a reactive result. The confirmatory assay showed a viral load of 8,310 copies/ $\mathrm{mL}$. This donor was invited to return and provided another blood sample, which exhibited seroconversion (Table 5). The index sample was concomitantly reactive for anti-HBc. Donor is a male, 29y, heterosexual, who denied any behavior of risk for HIV acquisition in the period preceding the first donation.

Sequencing of the protease and reverse transcriptase genes revealed the presence of the M36I polymorphism in the protease sequence, which is compatible to an antiretroviral naïve isolate. Phylogenetic analysis, available through the Brazilian HIV Genotyping Algorithm site (http:// www.aids.gov.br/genotipagem) classified this isolate as a circulating recombinant form $\mathrm{B} / \mathrm{F} 1$, which is commonly found in HIV-infected persons in São Paulo city ${ }^{14}$.

\section{DISCUSSION}

We have demonstrated the feasibility of the routine use of an NAT "in-house" method for screening of blood donations for HCV and HIVRNA. The methodology presented a high sensitivity and specificity and the yield of NAT-only HIV donations was 1:102,469.

In our country, there are only a few theoretical exercises on the virtual NAT yield if applied to the Brazilian blood supply. KUPEK ${ }^{9}$ has shown that contrary to what has been postulated and observed in practice in most countries, the residual risk in Santa Catarina State is higher for HIV (between 1:10,000 - 1:20,000) than for HCV transmission (around 1:100,000). BARRETO et al. ${ }^{2}$ obtained a magnitude of risk of HIV transmission of 14.9 per million donations, based on first-time blood donors in São Paulo city, similar to AMORIM et al. ${ }^{1}$ for Rio de Janeiro donors. NAT data on Brazilian plasma, sent abroad in exchange for blood derivatives, has shown two reactive cases for HIV RNA among 1,159,241 putative EIA negative donations tested $(1: 579,620)^{11}$. Although these plasmas came from all Brazilian regions, it should be borne in mind that São Paulo and Rio represent a significant fraction of the donated blood in Brazil. This data must be interpreted with caution, since it is not informed the brand and type of antibody assay by which these donations were screened, neither if the corresponding donors were traced back and tested for seroconversion and confirmatory NAT assays. However, it shall be pointed out that the numbers from the exported plasma are closer to the international experience and provides a NAT HIV yield thirteen times smaller than the estimate of BARRETO et $a ._{.}{ }^{2}$ and AMORIM et al. ${ }^{1}$ (1:33,333), as illustrated in Table 6 . In the US, a recent compilation of the data ${ }^{16}$ shows a yield of NAT isolated HIV reactive donations of 1:3,100,000, which is three times lower than previous estimates $(1: 1,000,000)^{14}$.

This discrepancy may be interpreted as if these calculations had overestimated the yield of NAT in Brazil. This could be due to the great deviations of these estimations with large confidence intervals. If we assume, for the numbers collected in this study, either a Poisson or a

Table 5

Laboratory data from a NAT+/EIA- donor, detected in the window period

\begin{tabular}{|c|c|c|c|c|c|}
\hline Date & $\begin{array}{l}\text { Anti HIV A } \\
\text { (Abs/Cut-off) }\end{array}$ & $\begin{array}{l}\text { Anti HIV B } \\
\text { (Abs/Cut-off) }\end{array}$ & NAT & $\begin{array}{l}\text { Viral load } \\
\text { copies/mL }\end{array}$ & Western blot \\
\hline $\begin{array}{l}27 / 2 / 6 \\
\text { Index donation }\end{array}$ & NRT & NRT & RT & $\begin{array}{c}8,310 \\
\left(\log _{10}=3.92\right)\end{array}$ & $\begin{array}{c}\text { Ind p24+ weak } \\
\text { Conclusion: Indeterminate }\end{array}$ \\
\hline $9 / 3 / 6$ & 2.0/0.198 (RT) & $1.91 / 1.00(\mathrm{RT})$ & RT & $>750,000$ & $\begin{array}{c}\text { Ind p24+ weak } \\
\text { Conclusion: Indeterminate }\end{array}$ \\
\hline $20 / 3 / 6$ & 2.0/0.181 (RT) & $6.25 / 1.00(\mathrm{RT})$ & RT & $>750,000$ & $\begin{array}{l}\text { gp160 weak/gp } 120 \text { weak/p24 weak } \\
\text { Conclusion: Reactive }\end{array}$ \\
\hline
\end{tabular}

NRT $=$ Non Reactive; RT $=$ Reactive 


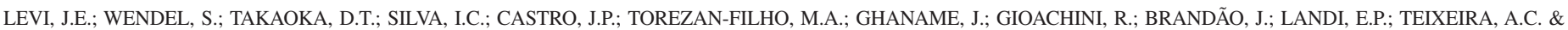
DURIGON, E.L. - Replacement of HIV p24 Ag test by a multiplex RT-PCR method for primary screening of blood donors. Rev. Inst. Med. trop. S. Paulo, 49(3): 171-176, 2007.

Table 6

Residual risk of HIV transmission from serologically negative donations at different Brazilian blood banks

\begin{tabular}{lccc}
\hline Center & Risk & $\begin{array}{c}\text { Time Period } \\
\text { Estimates }\end{array}$ & Reference \\
\hline HEMOSC & $1: 10,000-1: 20,000$ & $1999-2001$ & KUPEK, E. (2004) \\
HEMORIO & $1: 33,333$ & $1997-2000$ & AMORIM, L. et al. (2002) \\
HEMOSP(First-time donors) & $1: 50,000-1: 100,000$ & $1998-2001$ & BARRETO, C. et al. (2005) \\
HEMOSP(Repeat donors) & $1: 64,000$ & $1996-1998$ & SABINO, E. et al. (1999) \\
\hline & & Observed yields & MAC DOWELL, B. et al. (2004) \\
\hline Exported Brazilian plasma & $1: 580,000$ & $2002-2003$ & WENDEL, S. et al. (2002) \\
Several private blood banks & $1: 103,000$ & $1996-2001$ & LEVI, J.E. et al. (this paper) \\
Several private blood banks & $1: 103,000$ & $2001-2006$ & \\
\hline
\end{tabular}

binomial distribution and a confidence interval of $95 \%$, we get a very wide range for the NAT yield (1:4,048,583 - 1:18,382), emphasizing the limited epidemiological value of the data presented in this paper, principally because of the still relatively small sampling size.

Also, one can hypothesize that the larger risk predicted by BARRETO et al. ${ }^{2}$ and AMORIM et al. ${ }^{1}$ was reduced by the pooled analysis with plasma coming from Brazilian regions presenting much lower risk. In addition, Brazilian plasma was tested in pools of 96 1,000 samples $^{11}$. This large dilution factor could have contributed to the low yield observed. Knowing the origin of the NAT isolated reactive donations would certainly increase the scientific basis of the debate, but unfortunately this information is yet not published.

Possibly, a degree of uncertainty on the data stems from an unpredictable donor behavior; those willing to donate in order to be HIV tested, especially shortly after incurring on risky practices ${ }^{8}$. This may explain why we found an HIV p24 Ag reactive sample ${ }^{19}$ before an isolated HCV-NAT one, and another hospital in São Paulo found the same $^{18}$. If this kind of behavior is more often found in large cities like São Paulo, it would justify our findings and the contrast to what was observed on the exported plasma. However, the striking approximation of the rate of the two seroconversions detected by us; $1: 103,740$ $\left(\mathrm{p} 24 \mathrm{Ag}^{19}\right.$ ) and 1:102,469 (NAT, this article) suggests that in our donor population, the NAT-only HIV yield shall be around 1:100,000 donations.

Certainly, there are advantages and disadvantages of developing and routinely performing an "in-house" method. Lower cost, technological independence and agility to adapt for the detection of emergent agents may be arguments in favor of homebrew assays. On the other hand, it is unarguable that high-quality commercial kits provide lot-to-lot consistency, guaranteed performance and reagent stability that can hardly be accomplished by university and blood bank laboratories, unless a rigid control of the process is followed.

In conclusion, the decision of implementing NAT testing for HIV is, nowadays, not limited by the technical performance of the assays, either for "in-house" or commercial tests available. What makes its introduction not widely available is the high cost associated. Certainly in the future, when such methods become more accessible, NAT will be a routine test in hemotherapy, and probably "pooling" won't be necessary anymore. At this moment we believe that NAT-HIV is still not a mandatory test for blood and hemocomponents used for transfusional purposes by the Brazilian national blood system because of its unfavorable cost-benefit analysis. However, if hemoderivatives are to be manufactured from unused fresh frozen plasma, NAT will be mandatory in order to cope with international GMP standards for the plasma industry.

Due to scientific, economic and operational reasons we believe that NAT for Blood Banks, if and when introduced, shall be executed on a few specialized and trained molecular biology laboratories, which would analyze hundreds to thousands donations daily.

\section{RESUMO}

\section{Substituição do teste de p24 Ag (HIV) por um RT-PCR multiplex na triagem primária de doadores de sangue}

O uso de testes de ácidos nucleicos (NAT) na rotina de triagem de doadores de sangue tornou-se uma realidade ao final da década de 1990. Descreve-se aqui uma metodologia de RT-PCR multiplex "in-house" que permite a detecção simultânea dos RNAs dos vírus HIV e HCV além de uma molécula artificial de RNA usada como controle externo. $\mathrm{O}$ método detecta todos os subtipos de HIV do grupo M e também do grupo $\mathrm{N}$ e $\mathrm{O}$, com uma sensibilidade de $500 \mathrm{UI} / \mathrm{mL}$. Após validação, este teste substituiu o do antígeno p24, até então na rotina de triagem em nosso laboratório, desde 1996. De julho de 2001 a fevereiro de 2006 foram testadas 102.469 doações e $41(0.04 \%)$ foram NAT reativas. Uma doação NAT isoladamente reativa (anticorpo não-reativa) foi detectada com soroconversão subseqüente do doador, portanto, o rendimento do NAT nesta população até o presente momento é de 1:102.469. Este número contrasta com a experiência obtida internacionalmente, onde taxas de 1:600.000 - 1:3.100.000 foram descritas.

\section{ACKNOWLEDGMENTS}

We thank Dr. Susan L. Stramer (American Red Cross, Gaithersburg, MD, USA) for sharing data on NAT-only donations observed in the USA. 
LEVI, J.E.; WENDEL, S.; TAKAOKA, D.T.; SILVA, I.C.; CASTRO, J.P.; TOREZAN-FILHO, M.A.; GHANAME, J.; GIOACHINI, R.; BRANDÃO, J.; LANDI, E.P.; TEIXEIRA, A.C. \& DURIGON, E.L. - Replacement of HIV p24 Ag test by a multiplex RT-PCR method for primary screening of blood donors. Rev. Inst. Med. trop. S. Paulo, 49(3): 171-176, 2007.

\section{REFERENCES}

1. AMORIM, L.; CARVALHO, S.; DIAS, S.; LOBO, C. \& MOTTA, K. - Residual risk for transfusion-transmitted HIV and cost-benefit for HIV nucleic acid amplification technology (NAT) in Brazil. Transfusion, 42 (suppl. 3): 53, 2002. (Abstract S8030B).

2. BARRETO, C.C.; SABINO, E.C.; GONÇALEZ, T.T. et al. - Prevalence, incidence, and residual risk of human immunodeficiency virus among community and replacement first-time blood donors in São Paulo, Brazil. Transfusion, 45: 1709-1714, 2005.

3. CLELAND, A.; DAVIS, C.; ADAMS, N. et al. - Development of multiplexed nucleic acid testing for human immunodeficiency virus type 1 and hepatitis $\mathrm{C}$ virus. Vox Sang. (Basel), 81: 93-101, 2001

4. COSTE, J.; REESINK, H.W.; ENGELFRIET, C.P. et al. - Implementation of donor screening for infectious agents transmitted by blood by nucleic acid technology: update to 2003. Vox Sang. (Basel), 88: 289-303, 2005.

5. HEWLETT, I.K. \& EPSTEIN, J.S. - Food and Drug Administration conference on the feasibility of genetic technology to close the HIV window in donor screening (conference report). Transfusion, 37: 346-351, 1997.

6. JACKSON, B.R.; BUSCH, M.P.; STRAMER, S.L. \& AUBUCHON, J.P. - The costeffectiveness of NAT for HIV, HCV, and HBV in whole-blood donations. Transfusion, 43: 721-729, 2003.

7. JARVIS, L.M.; DOW, B.C.; CLELAND, A. et al. - Detection of HCV and HIV-1 antibody negative infections in Scottish and Northern Ireland blood donations by nucleic acid amplification testing. Vox Sang. (Basel), 89: 128-134, 2005.

8. KORELITZ, J.J.; BUSCH, M.P. \& WILLIAMS, A.E. - Antigen testing for human immunodeficiency virus (HIV) and the magnet effect: will the benefit of a new HIV test be offset by the numbers of higher-risk, test-seeking donors attracted to blood centers? Retrovirus Epidemiology Donor study. Transfusion, 36: 203-208, 1996.

9. KUPEK, E. - Transfusion risk for hepatitis B, hepatitis C and HIV in the State of Santa Catarina, Brazil, 1991-2001. Braz. J. infect. Dis., 8: 236-240, 2004.

10. LEVI, J.E.; CONTRI, D.G.; TAKAOKA, D.T. \& WENDEL, S. - PCR as a tool for primary screening of blood donors. Transfusion, 38 (suppl. 10): 57, 1998. (Abstract S207).
11. MAC DOWELL, B.; AMORIM, L.; SABACK, F.L.; MELO, H. \& MENDES, A. Resultados dos testes de biologia molecular (NAT) para os vírus HIV, hepatite B (HBV) e hepatite C (HCV) em doadores de sangue. In: CONGRESSO BRASILEIRO DE EPIDEMIOLOGIA, VI, Recife, 2004. Anais.

12. Ministério da Saúde/Brasil - Portaria No. 59. Available at: http://www.aids.gov.br/final/ diagnostico/portaria.htm

13. SABINO, E.C.; SALLES, N.; SÁEZ-ALQUÉZAR, A. et al. - Estimated risk of transfusion-transmitted HIV infection in São Paulo, Brazil. Transfusion, 39: 11521153,1999

14. SANABANI, S.; KLEINE NETO, W.K; KALMAR, E.M. et al - Analysis of the near full length genomes of HIV-1 subtypes B, F and BF recombinant from a cohort of 14 patients in São Paulo, Brazil. Infect. Genet. Evol., 6: 368-377, 2006.

15. SCHREIBER, G.B.; BUSCH, M.P.; KLEINMAN, S.H. \& KORELITZ, J.J. - The risk of transfusion-transmitted viral infections. The Retrovirus Epidemiology Donor Study. New Engl. J. Med., 334: 1685-1690, 1996.

16. STRAMER, S.L.; GLYNN, S.A.; KLEINMAN, S.H. et al. - Detection of HIV-1 and $\mathrm{HCV}$ infections among antibody-negative blood donors by nucleic acid-amplification testing. New Engl. J. Med., 351: 760-768, 2004.

17. STRAMER, S.L.; PORTER, R.A.; BRODSKY, J.P. et al. - Replacement of HIV-1 p24 antigen screening with HIV-1 RNA nucleic acid testing (NAT) for whole blood donations. Transfusion, 39 (suppl. 10): 29, 1999. (Abstract P8-020C).

18. TAKATU, P.M.; TAKATU, E.; STERZLING, L.N.; ROSENBLIT, J. \& POLITE, M.C. NAT detection in a blood donor at HIV antigen and antibody window period. First case reported in Brazil. Rev. bras. Hemat. Hemoter., 25 (suppl. 2): 239, 2003. (Abstract 789).

19. WENDEL, S.; FACHINI, R.M.; LEVI, J.E.; GHANAME, J.N. \& MENDONÇA, M.C. A single window period donation detected by HIV p24 Ag after 5 years of routine screening in a group of Brazilian blood banks. Vox Sang. (Basel), 83: 309-312, 2002 .

20. WENDEL, S.; LEVI, J.E.; TAKAOKA, D.T. et al. - Primary screening of blood donors by NAT testing for HCV-RNA: development of an "in-house" method and results. Rev. Inst. Med. trop. S. Paulo, 49: 177-185, 2007.

Received: 20 September 2005

Accepted: 24 November 2006 